\title{
Tax Evasion and Fraud Detection: A Theoretical Evaluation of Taiwan's Business Tax Policy for Internet Auctions
}

\author{
Shinemay Chen \\ Department of Public Finance, National Chengchi University \\ 64, Tz-nan Road, Sec. 2, Wenshan, Taipei 11623, Taiwan \\ E-mail: cmchen3@nccu.edu.tw \\ Jue-Shyan Wang (Corresponding author) \\ Department of Public Finance, National Chengchi University \\ 64, Tz-nan Road, Sec. 2, Wenshan, Taipei 11623, Taiwan \\ E-mail: jswang@nccu.edu.tw
}

\begin{abstract}
Only registered businesses can charge and collect taxes on goods and services made in Taiwan. As auction sites are places where individuals can conduct business activities for profit without paying business taxes, Taiwan's tax authority has ruled that profit-seeking individuals must register as businesses and pay taxes. However, the anonymity of sellers on Internet auction platforms poses challenges to the ability of the tax authority to enforce this ruling. This paper examines business tax policy for online auctions in Taiwan and then assesses the prospects of taxing sales on online auctions using a game theory model. Analytical results suggest that seller anonymity will allow a vendor to continue to disguise business identity and the tax authority will not aggressively pursue tax evaders.
\end{abstract}

Keywords: Online auction, Business tax, Taiwan, Tax evasion

\section{Introduction}

Online auctions are very successful in the West, and the Taiwanese public has recently showed that it enjoys this consumer-to-consumer (C2C) business model. As most online auction sites in Taiwan do not charge sellers fees for using their service, (Note 1) an increasing number of sellers have discovered that sellers selling through auction sites do not need to pay rents and taxes like vendors of brick-and-mortar stores do, and do not need to pay hosting fees and taxes like vendors of online shops do. That is, selling through auction sites reduces business costs. Hence, as the number of Internet user increases and electronic commerce grows at a significant rate, the use of online auctions as a marketplace for individuals and businesses will increase. (Note 2) That is, auction sites facilitate the sale of goods and services between individuals and for-profit businesses.

Taiwan's business tax has two fundamental forms, value-added and non-value-added taxes. (Note 3) Value-added business tax (hereafter, called business tax for simplicity) in Taiwan is imposed on sales of most goods and services within Taiwan and on imported goods. (Note 4) Thus, business activity via online auctions in Taiwan should be subject to business tax. Even so, the tax authority did not attempt to tax such trade until 2005. On May 4, 2005, Taiwan's tax authority instituted the Directions on the Levy of Business Tax and Income Tax on Transactions over the Internet, claiming that selling through virtual shops is subject to the same tax rules as selling through physical shops. (MOF, 2006) Accordingly, a taxable person and reporting policy under Taiwan's tax system hold for online auction transaction. The taxation regulations were enforced on online auctioneers starting November 5, 2005. However, according to the estimates of Taipei National Tax Administration (abbreviated as TNTA), (Note 5) business tax from sales made online is only 1/1000 of business tax from sales made by brick-and-mortar retailers from January to October 2008. In addition, the number of online vendors who have filed business registration is also $1 / 1000$ of the number of total registered businesses. (Wang, 2009) Evidently the estimates show that many online retailers do not comply with the new tax rules. (Note 6)

Although the tax neutrality principle suggests that no particular form of trade should be favored through the tax system, (Note 7) excessively expensive administrative procedures in fact preclude the feasibility of taxing online auction sales. In particular, seller anonymity is a challenge to the ability of tax collectors to generate the required 
verification.

Many studies have applied game theory to tax compliance and tax evasion associated with individual compliance with income tax (Allingham and Sandmo, 1972; Erard and Feinstein, 1994; Reinganum and Wilde, 1985, 1986; Bernasconi, 1998; and Lee, 2001). No studies other than those by Marrelli (1984), Murray (1995), and Alm et al. (2004) investigated firm compliance with indirect taxation. Marrelli (1984) applied a theoretical framework to investigate decisions to evade value-added tax for a risk-averse monopolist. Murray (1995) developed a sales tax compliance-enforcement paradigm for examining empirically the determinants of audit selection and audit productivity for the Tennessee sales tax. Alm et al. (2004) utilized a two-stage estimation model to examine an audit selection program administered by the New Mexico tax authority and firm compliance behavior.

On the other hand, most electronic commerce taxation issues are analyzed using legal perspectives (Fox and Murray, 1997; Hellerstein, 1997; Peha and Strauss, 1997; McLure, 1997, 1999; Gordon and Nielsen, 1997). Although several empirical (Cline and Neubig, 1999; Goolsbee and Zittrain, 1999; Meijers, 1998) studies have investigated the effect of electronic commerce on sales tax revenue or value-added tax revenue, few theory-based studies have examined these issues. Watanabe (2000) investigated the feasibility of applying income taxation and value-added taxation to electronic commerce in an international taxation context. To date, no study has analyzed tax evasion associated with electronic commerce taxation. Furthermore, no study has applied game theory to Internet auctions.

This paper, using Taiwan as a case study, analyzes the feasibility of imposing a value-added business tax on Internet auctions when the tax authority has difficulty identifying sellers and learning their sales figures. The remainder of this paper is organized as follows. Section II briefly discusses the business tax policy for Internet auctions. Section III outlines the problems associated with this tax. As there is no theoretical literature on tax evasion in the context of electronic commerce, Section IV examines the feasibility of taxing online auction sales using a simple game theory paradigm. Concluding remarks are presented in Section V.

\section{Business Tax Policy for Online Auction Transactions}

Taiwan's business tax has two principal forms: value added and non-value added. Value-added business tax is applied to general industry, whereas the non-value added business tax is applied to particular industries such as banking, insurance, investment trust, securities, futures, commercial paper and pawnshops. (Note 8) Business tax, following individual income tax and business income tax, is the third largest source of tax revenue in Taiwan. For the fiscal years 2001-2006, business taxation accounted for on average 16.5\% Taiwan's total tax revenues. (Note 9)

Business tax is charged on any sale of goods and services made in Taiwan. Goods exported through customs and services supplied within Taiwan and used in foreign countries are zero-rated and not subject to business tax. Consequently, those subject to business tax include domestic businesses and foreign-owned businesses established in Taiwan that sell goods or services, companies that import goods, and companies that pay for services provided by foreign businesses that have no fixed place of business in Taiwan. (Note 10)

Only a registered business can charge and collect business tax on goods or services sold in Taiwan with the exemption of zero-rated sales. Registered businesses must record and pay the collected business tax to the tax administration. For imported goods, business tax is payable directly to Taiwan Customs at the point of importation into Taiwan.

Any head office and branches with fixed places of establishment in Taiwan are required to register before opening. (Note 11) Under current tax laws, a vendor selling $>$ NT $\$ 80,000$ worth of goods a month is required by law to register and pay business tax. (Note 12) Notably, businesses selling goods or services must issue uniform invoices to buyers (Note 13 ) and apply a $5 \%$ business tax rate. However, a vendor with monthly sales revenue between NT\$80,000 and NT\$200,000 (Note 14) may be exempt from issuing uniform invoices and the applicable rate is either $1 \%$ or $5 \%$, depending whether uniform invoices are issued by the business? (Note 15)

Table 1 lists the business tax rules for businesses of different sizes. By issuing uniform invoices, a business is entitled to claim tax credits for business taxes paid on business inputs. However, a business that does not issue uniform invoices pays the business tax assessed by the tax authority, and input tax credits for the business tax paid on business inputs cannot be credited against the tax due.

The Business Tax Act does offer penalty provisions. A business entity failing to register may pay a fine of NT\$3,000-NT\$30,000. (Note 16) Additionally, such businesses must pay taxes and are fined 1-10 times the evaded amount. (Note 17)

The problem facing the tax authority is how to apply business taxes to electronic commerce transactions in 
which a party pays for physical goods, digitized goods and services. Taiwan's tax authority claimed that sales through virtual shops are subject to the same tax rules as selling through bricks-and-mortar shops. Therefore, the taxpayer and reporting policies under Taiwan's business tax system still holds for Internet transactions. That is, any business supplying goods or services in Taiwan via the Internet must collect business taxes as do conventional businesses. The mechanism through which a transaction occurs does not alter the taxability of a transaction.

Nevertheless, an online auction marketplace is where individuals buy and sell goods and services. (Note 18) Online auction sites do not require sellers to register as a business. Since those paying business taxes should be registered, (Note 19) traditional tax rules therefore unlikely to apply to a consumer-to-consumer commerce model. However, an increasing number of individuals are using online auctions to start a business, and even conventional businesses are starting to sell goods through auction sites to avoid paying business taxes. In response, Taiwan's tax authority has extended business tax jurisdiction to domestic individuals carrying out auction activity with the intention of making profit.

When an individual engages in for-profit activities through an online auction site, the seller is required to register as a business for tax purposes. The following criteria are considered when determining whether an individual is conducting a for-profit business: 1) an individual profits from a sale; 2) an individual has a stock inventory; and, 3 ) an individual sells goods that are not individual daily necessities. (Note 20)

That is, an individual who meets all three criteria with monthly sales of NT\$80,000 is required to register as a business and pay business taxes.

\section{Business Tax Dilemma of Online Auction}

It is important to understand that the feasibility of applying the business tax to online auctions depends on whether the tax authority can identify whether a transaction is regular trade (i.e., a for-profit sale) or occasional sale, and seller identity. However, one of the unique characteristic of online auctions is seller and buyer anonymity (Bajari and Hortacsu, 2003). Online auction sites in Taiwan, such as Yahoo! Kimo Auction and Ruten, do not require users to divulge their names or addresses; only seller ID or nickname is revealed. Due to this information asymmetry, when a given seller understands that he qualifies as a taxable entity (i.e., must register as a business) and does not voluntarily register as a business, the tax authority faces a series of challenges when attempting to detect the seller's identity.

\subsection{The Identification of Taxable Entity}

In order to know how much each trader made through online selling, the U.S. Treasury Department is seeking legislation requiring auction sites such as eBay, Amazon and uBid to disclose the Social Security numbers and identities of high-volume sellers(Note 21) to the Internal Revenue Service.

"A U.S. broker would be required to make an information return showing its customer's name, address and Taxpayer Identification Number, as well as gross proceeds from the sale of tangible personal property." (US Department of the Treasury, 2007)

More specifically, in an effort to track down unreported business income, the Internal Revenue Service believes that Internet companies should take part in tax collection and, therefore, proposes to expand information reporting.

Indeed, information is the key to maintaining the effective administration of taxes. The IRS proposal shows how tax authorities will get the information they need. However, Social Security numbers may need to be collected by online auction sites. Because these companies won't know until the end of the year which sellers have exceeded the reporting threshold, they will need to collect the necessary information from all sellers. And as sensitive personal information are spread among more databases, the possibility for identity theft and phishing scams rises.

On the contrary, privacy of personal information is properly respected by Taiwan's tax authority. The tax agent does not ask online auctioneers across-the-board information of sellers. Only when a suspected tax fraud is reported, the tax authority will then ask an auction site for offering detailed seller information on a case-by-case basis. In order to strengthen tax administration, the tax authority in Taiwan currently relies on feedback rating on the auction site to identify profit-seeking sellers. The voluntary feedback mechanism on online auction sites is a mechanism for assessing seller and buyer performance. A buyer can rate a seller's performance (and vice versa) by giving the seller a positive $(+1)$, neutral $(0)$, or negative $(-1)$ score. Online auction sites allow free access to these statistics,(Note 22) which are hyperlinked to user IDs. Hence, Taiwan tax authority believes a high number of ratings in indicative of a seller running an online auction business. To identify potential profit-seeking sellers 
with a high number of feedback scores, a tax inspector poses as a buyer or asks the auction site to provide detailed seller information.

Therefore, to successfully identify online vendors who should pay business taxes and determine the seller's revenue, the tax authority expends considerable financial resources in detection and auditing costs. For instance, Taipei National Tax Administration had 200 tax auditors disguise themselves as the buyers in the online auction transactions. (Chen, 2006)

On the other hand, sellers in Taiwan can avoid paying business taxes by registering several different IDs or by trading outside of auction sites. That is, to avoid notice from the tax authority, retailers first step reduce the number performance reviews. In doing so, a retailer can divide the business into several small businesses by registering different IDs; each ID would therefore have fewer performance reviews and lower sales revenues.

Undoubtedly, to evade business tax liability, an online auction vendor also bears penalty costs being caught. Furthermore, breaking an online auction business into several businesses and having multiple IDs jeopardize a seller's reputation.

\subsection{Audit of Sales Revenue}

When a seller who qualifies as a profit-seeking business is detected and is not a registered business, the business must pay taxes and is fined 1-10 times the amount of tax evaded. Since all trades are conducted in cyberspace, and relevant information is recorded electronically, identifying the amount of tax a seller evades is challenging.

Auditing methods for electronic commerce transactions is a developing area worldwide. The auditing methods must be comprehensive to include an array of issues like digital signatures, electronic data and record keeping rules, costs assessments, and software and other website related expenses. As far as this research goes, there is no country with a comprehensive method to audit electronic commerce businesses.

In summary, tax collectors face two challenges when attempting to apply business taxes to Internet auction transactions. The first challenge is identifying sellers who qualify as taxable businesses (i.e., a profit-seeking business). Seller anonymity makes identification difficult and the tax authority expends considerable manpower attempting to identify such sellers. Another problem is auditing sales revenue once a seller is identified as a profit-seeking business. Hence, the feasibility of taxing online auction sales warrants further investigation.

\section{Evaluation of Taxing Online Auction-The Model}

Although online retailers should pay taxes, how to implement such taxation is a major challenge. Sandmo (2005) noted that, when collecting taxes, the tax authority bears the costs associated with assessing tax liability, reviewing tax returns, and pursuing tax evaders. However, identifying sellers who qualify as taxable businesses on online auction sites generate significant costs for the tax authority. Conversely, online auction sellers who qualify as a taxable business also has compliance costs and loses price competitiveness when applying taxes to sold goods and services. Therefore, the feasibility of taxing sales in online auctions is based on the auditing policy of the tax authority and opportunities for tax evasion.

\subsection{Assumptions}

In examining explicitly taxpayer evasion behavior in an online auction setting, this study applies a simple gaming paradigm. Since the location and identification of potential taxpayers on the Internet are ambiguous for the tax authority, business entities, including individuals conducting for profit-seeking transactions over the Internet within Taiwan, are required to register their businesses for tax purposes before commencing business. After filing the business registration, an online vendor must obtain a tax file number and periodically pay taxes by law. That is, to maintain effective tax administration, the tax authority must acquire the necessary information about online sellers. However, if an online trader does not register for tax purposes, the tax authority cannot do anything other than visit Internet auction sites, and attempt to identify who conducting profit-seeking activities and did not register.

Before discussing the model, this study needs to differentiate between three categories of sellers who are required to register as taxable businesses (see Table 1). The first category is a seller whose monthly sales revenue is NT $\$ 80,000-\$ 200,000$ and does not issue uniform invoices. In this case, a seller should pay business taxes assessed by the tax authority, and the input tax credits for business tax paid on business inputs cannot be credited against tax due. The second category is a seller whose monthly sale revenue is NT $\$ 80,000-\$ 200,000$ and issue uniform invoices. In this case, a seller can claim input tax credits for business taxes paid on business inputs. The third category is a seller whose monthly sales revenue is $>\mathrm{NT} \$ 200,000$ and is required to issue uniform invoices. By issuing uniform invoices, the seller can claim input tax credits for business tax paid on business inputs. 
We assume that when monthly sales revenue is $>\mathrm{NT} \$ 80,000$, a seller would issue uniform invoices if he registers for tax purposes. That is, the first seller type is excluded; otherwise, both sales revenue and business tax due are assessed by the tax authority and not by the seller.

Tax evasion literature treats tax evasion as the underreporting of tax liability. However, Sandmo (2005) noted that during tax evasion, taxpayers attempt to hide their actions from the tax authority. Such behavior includes hiding one's identity as a taxable entity. Hence, in the context of online auctions, we assume that not registering as a business is the only method of evading business tax liability. Once a seller registers, a seller would honestly pay business tax.

\subsection{The Model}

This paper analyzes the feasibility of imposing a value-added business tax on Internet auctions when the tax authority has difficulty identifying sellers and learning their sales figures. In the case of Taiwan, since requiring a profit-seeking seller to register for tax purposes is the first step toward effective tax enforcement and administration; thus, this paper configures an online business tax-evasion problem as a registration-detection game.

Consider a two-player strategic-form game in which each player has a strategy space containing two actions. Player 1 is a vendor qualified as a profit-seeking seller on an online auction site, and player 2 is the tax authority. Player 1's pure strategies are either to evade (not to register) or not to evade (to register) business taxes. (Note 23) Player 2's pure strategies are either to detect or not to detect the vendor. Assume that both players act simultaneously, or player 1 acts first and player 2 cannot observe the actions of player 1.

Sales revenue of player 1 is $R$, and total cost is a fraction of sales revenue equal to $c R$, where $0<c<1$. Business tax is levied as a constant, $t$. Typically, the authority can expend resources to attempt to identify online vendors. Hence, we assume that the government's cost in auditing online auction business is $F$. With some probability $\theta$, where $\theta \in(0,1)$, the online vendor is investigated by the authority, which will then acquire data for all transactions between a seller and buyers.(Note 24) When a seller that should be registered as a business is identified, the seller will pay a penalty rate of, $\alpha$, where $\alpha>1$ on the tax amount evaded.

Figure 1 presents the strategy spaces of players and their payoff function, i.e., a two-player normal-form game with a finite strategy set.

\section{Insert Figure 1 Here}

Based on the Nash Equilibrium, this study defines the following six existing equilibriums. A sketch of the proof appears in Appendix.

Equilibrium 1:

The online retailer chooses to evade business taxes and the tax authority chooses to identify this retailer; that is, the player equilibrium strategy set is (Evade, Detect). This equilibrium will stand when

$\theta \alpha \leq 1-c, \theta \alpha t R \geq F$

Equilibrium 2:

When the online retailer chooses to evade business taxes and tax authority chooses not to attempt to identify this retailer; that is, the player equilibrium strategy set is (Evade, Not Detect). This equilibrium will stand when $\theta \alpha t R \leq F$.

Equilibrium 3:

When the players' equilibrium strategy set is $((F /(\theta \alpha t R), 1-F /(\theta \alpha t R)),((1-c) /(\theta \alpha), 1-(1-c) /(\theta \alpha)))$, i.e., both players are indifferent to their two pure strategies and choose the strategy to play randomly, then this equilibrium will stand when $\theta \alpha>1-c, \theta \alpha t R>F$.

Equilibrium 4: 
When an online retailer decides to evade business taxes and the taxes authority applies a mixed strategy, the equilibrium strategy set is (Evade, $\left.\left(q_{1}, 1-q_{1}\right)\right)$, where $q_{1} \in(0,(1-c) / \theta \alpha]$. This equilibrium stands when

$\theta \alpha>1-c, \theta \alpha t R=F$

Equilibrium 5:

When an online retailer decides to evade business taxes and the authority utilizes a mixed strategy, the players' equilibrium strategy set is (Evade, $\left(q_{2}, 1-q_{2}\right)$ ), where $q_{2} \in(0,1)$. This equilibrium stands when $\theta \alpha \leq 1-c, \theta \alpha t R=F$

Equilibrium 5 differs from Equilibrium 4 in the relative size of $\theta \alpha$ and 1-c. This different relative size yields different mixed strategy outcomes.

Equilibrium 6:

When an online retailer utilizes a mixed strategy and the authority plays "detect" strategy, the players' equilibrium strategy set is $((p, 1-p)$, detect), where $p \in[F /(\theta \alpha t R), 1)$. This equilibrium stands when $\theta \alpha=1-c, \theta \alpha t R>F$

Of these equilibriums, Equilibrium 1 and Equilibrium 2 are pure strategy Nash equilibriums, whereas the others are mixed strategy Nash equilibriums.

Taking $\theta \alpha$ and $\theta \alpha t R$ as horizontal axis and vertical axis, respectively, the seven regions (Figure 2) can be defined to identify possible equilibriums among all variables. Table 2 presents the scope of each region.

Applying the scope of 7 regions and conditions of 6 Nash equilibriums yield Proposition 1.

Proposition 1: When taxing sales in online auctions, Nash equilibrium exists in each region is shown as Table 3.

Summarizing the above analysis and the outcome of Proposition 1 demonstrates that for online auction taxation, the Nash equilibriums that include the "not evade" pure strategy does not exist. This result is primarily because among Nash equilibrium sets, when the online vendor chooses the "not evade" pure strategy, the tax authority chooses not to inspect; and when the tax authority chooses the "not detect" pure strategy, then the online vendor chooses to evade business tax. (Note 25) This leads to the following proposition.

Proposition 2: For taxing online auctions, the Nash equilibriums including the "not evade" pure strategy do not exist.

Furthermore, if Nash equilibriums are further examined, the online vendor will adopt a mixed strategy that includes not evading business tax. Consequently, among the six Nash equilibrium sets, Equilibrium 3 and Equilibrium 5 lead to the following corollary.

Corollary 1: When the conditions $\theta \alpha \geq 1-c$ and $\theta \alpha t R>F$ are satisfied, the online vendor will choose the mixed strategy that incorporates a "not evade" strategy.

The condition $\theta \alpha \geq 1-c$ indicates that the probability of receiving a penalty and penalty rate should be sufficiently to concern online vendors. That is, high penalties and audit probability discourage tax evasion, a finding that is consistent that obtained by Allingham and Sandmo (1972). The second condition, $\theta \alpha t R>F$, suggests that penalty revenue should exceed auditing cost. The penalty rate and business tax rates are policy variables that cannot be changed at this time. Hence, detection probability and auditing cost are decisive factors 
when online auction sellers consider registering as a business.

In addition, the expected payoffs of player 2 (the government) associated with six Nash equilibriums are summarized as Table 4.

In all of these equilibriums given corresponding conditions, the payoffs for Equilibriums 1, 3, and 6 are greater than zero. When compared to the relative size of $\theta \alpha$ and 1-c among the three equilibriums, Equilibrium 3 yields the greatest payoff to player 2 (the government). Therefore, if the government wants to increase its payoff in an online retailer-government game, the government must establish a condition that satisfies $\theta \alpha>1-c$ and $\theta \alpha t R>F$, i.e., the $A_{3}$ region, to yield a corresponding and unique equilibrium-Equilibrium 3. Put simply, the government must raise the likelihood of fraud detection, $\theta$, and the penalty rate, $\alpha$.

Proposition 3: To increase the equilibrium payoff in this registration-detection game, the government must increase the probability of fraud detection, $\theta$, and punishment rate, $\alpha$.

That is, increases in the severity of punishments and advances in techniques for detecting online seller identities affect the incidence of tax evasion.

In the case of online auctions, seller anonymity causes the tax authority to expend considerable resources to locate a potential taxable business, and online auction vendors enjoy a low probability of being caught. Consequently, vendors will likely continue to disguise their business identities and the tax authority will not aggressively pursue tax evaders.

However, by examining the voluntary feedback mechanisms on online auction sites, the tax authority has increased likelihood of locating vendors that should pay business taxes. Therefore, sellers on online auction sites with a high number of feedback scores have a higher probability than those with few scores of being detected.

\section{Concluding Remarks and Policy Implication}

The problems for collection of tax are not new in principle, but existing issues make more poignant by the speed and spread of the Internet. This study analyzed business tax issues related to Taiwan's online auction business, and applied a $2 \times 2$ simultaneous game theory model to illustrate the prospects of taxing sales on online auctions. Requiring a profit-seeking individual to register for tax purposes is the first step toward effective tax enforcement and administration; thus, this study configures an online business tax-evasion problem as a registration-detection game.

Analytic results of the simultaneous game demonstrate that it's very much possible for a "evade" strategy to exist in pure strategy Nash equilibriums, while a "not evade" strategy only exists in mixed strategy equilibriums. This finding is consistent to the reality of online auctions. To increase the equilibrium payoff in the registration-detection game, the tax authority must increase the likelihood of detecting tax evasions and increase associated penalties. However, the penalty rate is fixed in Taiwan and cannot be changed at this time. Thus, Taiwan's tax authority has no option other than increasing probability of detecting tax evasions. Nevertheless, increasing the probability of detection is not equivalent to increasing detection frequency. At present, detection cost is a constant as it is included in rigid departmental budgets and the salary structure of tax inspectors. With no additional rewards for detecting tax evasion, a tax auditor will do little more than routine work, and, thus, detection frequency is fixed. Increasing the probability of detecting tax evasion is equated with increasing the probability of discovering tax evasion. In an Internet environment, if the tax authority tries to enforce taxes solely by increasing the detecting frequency, they will soon find that actions are like beating the bushes. Detection technique, not detection frequency, is key to identifying sellers. The tax authority in Taiwan currently relies on feedback ratings on auction sites to identify profit-seeking sellers. However, due to seller anonymity, to obtain information about a suspect, tax inspectors need an auction company to disclose details about sellers on a case-by-case basis. Therefore, at present, tax administrators will find the task of detecting online tax evasion difficult. Restated, the probability of detecting online vendors is reduced.

Taiwan's online auction market is not active in cross-border transactions, and online auction companies, such as Yahoo! Kimo, generate a consumer marketplace. The limited share of cross-border trade and neutrality of online auctioneers results in a game with two players. However, online auction markets in, say, the US and EU member states, are very active in cross-border or interstate sales. Consequently, an online tax evasion game may involve 
three players. For instance, in the US, under the ruling for Quill Corp. v. North Dakota, 504 U.S. 298 (1992), an online business must be "physically present" in a state before that state can require the business to collect a use-based tax (a companion tax to sales tax) on its behalf. An out-of-state vendor that merely has an "economic presence" in a state is not required to register to collect use taxes on their sales. Nevertheless, an in-state online vendor is required to register to collect sales taxes on their in-state sales. Therefore, if an online vendor purposely practices sales tax evasion, that vendor would not register in any state and, thus, state authorities would have no way of identifying the geographic locations of buyers. Likewise, if the annual turnover of a vendor in the EU is less than certain limit (i.e., the VAT registration threshold, e.g., $£ 67,000$ annual sales in UK), the vendor does not have to charge VAT on their "in-state" sales.(Note 26) While a VAT-registered vendor selling to an individual customer in a different EU country (so-called distance selling) must collect the VAT at the rate in the seller's home country; once supplies exceed a certain level, e.g., $£ 70,000$ or more in the UK, a distant seller are required to register in that other member state. Thus, when a transaction occurs online, no audit trail exists for tax authorities to ensure that parties are complying with rules.(Note 27)

Although this study analyzes the feasibility of taxing online auction sales takes Taiwan as a case study, policy implications apply to other countries, including the US and EU member states. To increase tax compliance, the US Treasury Department, in the President's 2008 budget, required online auction sites such as eBay to share personal data with the Internal Revenue Service (IRS). However, this move proved highly offensive to US privacy groups and no lawmaker has yet supported this move. The tax authority in Taiwan is not authorized to ask online auction sites to provide seller information. Since information is key to effective taxation and increasing the likelihood of detecting tax evasion, if privacy rights are respected, then tax authorities around the world must generate a new practical means for collecting sales or value added tax revenue on online auction sales.

To successfully apply the business tax policy to online auctions, Taiwan's tax authority perhaps should consider raise the penalty rate in the long run.

\section{Appendix}

Assume that player 1 (online retailer) chooses to evade business taxes with probability $p$ and not to evade business taxes with probability $1-p$, and player 2 (the government) chooses to detect this retailer with probability $q$ and not to detect this retailer with probability $1-q$. The expected gains for both players are as follows.

For player 1, the expected gain when choosing evading strategy is

$$
q R(1-c-\theta \alpha t)+(1-q) R(1-c)=R(1-c)-q R \theta \alpha t,
$$

and the expected gain when choosing no evading strategy is

$$
q R(1-c)(1-t)+(1-q) R(1-c)(1-t)=R(1-c)(1-t) .
$$

Accordingly, when the condition $(1-c)>(<) q \theta \alpha$ stands, player 1 will play evading (not evading) strategy.

For player 2, the expected gain when choosing detecting strategy is

$$
p(\theta \alpha t R-F)+(1-p)(t R-F)=[p \theta \alpha+(1-p)] t R-F
$$

and the expected gain when choosing no detection strategy is

$$
p \cdot 0+(1-p) t R=(1-p) t R
$$


Accordingly, when the condition $p \theta \alpha t R>(<) F$ stands, player 2 will play detecting (not detecting) strategy.

Using the decision profile of both players, six equilibriums are obtained. Take Equilibrium 4 and Equilibrium 5 as examples. When player1 (online retailer) adopts evading strategy, i.e., $p=1$, player 2 (the government) will apply a mixed strategy if $\theta \alpha t R=F$. As mention earlier, the necessary condition for player 1 choosing a

evading strategy is $(1-c) \geq q \theta \alpha$. Therefore, when $\theta \alpha>1-c$ and $q \in\left(0, \frac{1-c}{\theta \alpha}\right],(1-c) \geq q \theta \alpha$ is

satisfied. Equilibrium 4 is then obtained. However, when $\theta \alpha \leq 1-c,(1-c) \geq q \theta \alpha$ is satisfied irrespective of the value of $q$. In this case, Equilibrium 5 is obtained.

\section{References}

Allingham, Michael G. \& Agnar Sandmo. (1972). Income tax evasion: a theoretical analysis. Journal of Public Economics, 1(3/4): 323-338.

Alm, James, Calvin Blackwell, \& Michael McKee. (2004). Audit selection and firm compliance with a broad-based sales tax. National Tax Journal, 57: 209-227.

Bajari, Patrick \& Ali Hortacsu. (2003). Economic insights from Internet auctions. NBER Working Paper No. 10076, New York: National Bureau of Economic Research.

Basu, Subhajit. (2004). To tax or not to tax? That is the question? Overview of options in consumption taxation of E-commerce. Law Technology, 37(2): 1-41.

Bernasconi, Michele. (1998). Tax evasion and orders of risk aversion. Journal of Public Economics, 67: 123-34.

Chen, Mei Chen. (2006). 200 Tax policemen surfing the web to detect taxes. Economics Daily, July 14, 2006, A13. (In Chinese)

Cline, Robert J., \& Thomas S. Neubig. (1999). The sky is not falling why state and local revenues were not significantly impacted by the Internet in 1998. [Online] Available: http://www.law.gmu.edu/techcenter/programs/advisory_commission/document/skyIsNotFalling.pdf (June 28, 2007).

Erard, Brian \& Jonathan S. Feinstein. (1994). Honesty and evasion in the tax compliance game. RAND Journal of Economics, 25: 1-19.

Fox, William F. \& Matthew N. Murray. (1997). The sales tax and electronic commerce: So what's new. National Tax Journal, 50: 573-592.

Goolsbee, Austan \& Jonathan Zittrain. (1999). Evaluating the costs and benefits of taxing Internet commerce. National Tax Journal, 52(3): 413-428.

Gordon, Roger H. \& Soren Bo Nielsen. (1997). Tax evasion in an open economy: value-added vs. income taxation. Journal of Public Economics, 66: 173-197.

Hellerstein, Walter. (1997). Transaction taxes and electronic commerce: Designing state taxes that work in an interstate environment. National Tax Journal, 50: 593-606.

Internal Revenue Service. (2007). Business or hobby? Answer has implications for deductions. [Online] Available: http://www.irs.ustreas.gov/newsroom/article/0,,id=169490,00.html (July 31, 2008).

Lee, Kangoh. (2001). Tax evasion and self-Insurance. Journal of Public Economics, 81: 73-81.

Market Intelligence Center. (2006). C2C consumption trends of Taiwan' Internet users, 2006. Taipei, Taiwan: Market Intelligence Center, Institute for Information Industry [Online] Available: http://mic.iii.org.tw/ (September 20, 2006).

(2007). The factor analysis of success in Taiwan's Internet auction. Taipei, Taiwan: Market

Intelligence Center, Institute for Information Industry [Online] Available: http://mic.iii.org.tw/ (December 14, 
2007).

Marrelli, Massimo. (1984). On indirect tax evasion. Journal of Public Economics, 25: 181-196.

McLure, Charles E., Jr. (1997). Electronic commerce, state sales taxation, and intergovernmental fiscal relations. National Tax Journal, 50: 731-749.

(1999). Electronic commerce and state retail sales tax: a challenge to American federalism. International Tax and Public Finance, 6: 193-224.

Meijers, Huub. (1998). Internet trade and the tax leak: A quantitative analysis for the Netherlands. Paper presented at the Second Berlin Internet Economics Workshop, 28-29 May. 1998 [Online] Available: http://www.berlecon.de/iew2/papers/ meijers.pdf (Oct. 31, 2006).

Mikesell, John L. (2000). Remote vendors and American sales and use taxation: The balance between fixing the problem and fixing the tax. National Tax Journal, 53: 1273-1286.

MOF (Ministry of Finance). (2006). Directions on the levy of business tax and income tax on transactions over the [Online] Available: http://www.dot.gov.tw/display/show.asp?id=1665\&lang=2\&expand=2\&thisitem=70\&modify=1 (December 23, 2008).

Murray, Matthew N. (1995). Sales tax compliance and audit selection. National Tax Journal, 48: 515-529.

National Tax Administration of Northern Taiwan Province, Ministry of Finance. (2005). Introduction of Electronic Commerce (In Chinese).

Peha, Jon M. \& Robert P. Strauss. (1997). A primer on changing information technology and the fisc. National Tax Journal, 50: 607-621.

Reinganum, Jennifer F. and Louis L.Wilde. (1985). Income tax compliance in a principal-agent framework. Journal of Public Economics, 26: 1-18.

(1986). Equilibrium verification and reporting policies in a model of tax compliance. International Economic Review, 27: 739-760.

Sandmo, Agnar. (2005). The theory of tax evasion: A retrospective view. National Tax Journal, 58(4): 643-663.

Taipei National Tax Administration. (2005). Rules for levying business and income tax on Internet transactions [Online] Available: http://www.ntat.gov.tw/county/ntat_ch/download/Net_Taxrule.pdf. (In Chinese) (August 20, 2006).

US Department of the Treasury. (2007). General explanations of the Administration's fiscal year 2008 revenue proposals [Online] Available: http://www.treas.gov/offices/tax-policy/library/bluebk07.pdf (December 20, 2007).

Wang, Hsing - Zen. (2009). Taxing online sales, a big challenge to the tax authority, China Times. [Online] Available:

http://tech.chinatimes.com/2007Cti/2007Cti-News/2007Cti-News-Print/0,4634,12050903x122009020100079,00 .html (1 February 2009).

Watanabe, Satoshi. (2000). Electronic commerce, international taxation, and administration. Hitotsubashi Journal of Economics, 41: 53-64.

\section{Notes}

Note 1. Yahoo! Kimo Auction is the only auctioneer charging auction fees in Taiwan. The site started charging its online sellers a listing fee of NT\$3 per item on April 9, 2004 and began charging a 3\% transaction fee on September 1, 2006.

Note 2. A 2008 survey conducted by the Institute for the Information Industry's Market Intelligence Center demonstrated that $69 \%$ of Taiwan's Internet users have traded on auction sites in 2008. The value of online auctions transactions reached NT\$31 billion in 2005, NT\$51.6 billion in 2006, NT\$77.4 billion in 2007, and will likely reach NT\$107.1 billion in 2008. (Market Intelligence Center, 2008)

Note 3. See Article 1 of the Value-Added and Non-Value-Added Business Tax Act (hereafter, the Business Tax Act). English version of the Business Tax Act can be obtained on official website of Taxation Agency, Ministry of Finance. http://www.dot.gov.tw/display/show.asp?id=1087\&lang=2\&expand=2\&thisitem=70\&modify=1. Accessed 1 May 2008.

Note 4. Article 1 of the Business Tax Act. 
Note 5. TNTA has 2 branches and 11 offices to collect national taxes in Taipei.

Note 6. In 2007, online retailing was worth about NT\$183.62 billion, accounting about 5.6\% of Taiwan's total retail sales.

Note 7. Taxpayers in similar situations performing similar transactions should be subject to similar levels of taxation. (Basu, 2004)

Note 8. See Article 1-1 of the Business Tax Act.

Note 9. Business income tax and individual income tax account for on average $18.4 \%$ and $18.7 \%$ of the total tax revenues, respectively.

Note 10. Article 2 of the Business Tax Act.

Note 11. Article 28 of the Business Tax Act.

Note 12 . In the UK, the VAT registration threshold currently is $£ 67,000$ for the previous 12 months.

Note 13. Article 3 of the Business Tax Act. The system of uniform invoices, developed in 1951, was choreographed by Taiwan's tax authority. In Taiwan, uniform invoices are the standard-form, numbered sales receipts that nearly all businesses in Taiwan are legally required to issue to their customers. This system was devised for successful collection of tax revenue and the convenience of subsequent tax auditing processes. To achieve these goals, uniform invoices also double as lottery tickets. On the 25 th of every odd month, one winning number for the grand prize and three to ten sets of winning numbers for other prizes will be drawn from the uniform invoices issued in the previous period. The cash award of the grand prize can be as much as NT\$2 million. With the prize incentives, buyers will ask for uniform invoices whenever they do the purchases. Therefore, businesses are not able to evade paying taxes.

Note 14. Such vendor is defined as a "small-scale enterprise".

Note 15. Article 13, 14, and 23 of the Business Tax Act.

Note 16. Business Tax Act, Article 45. Such penalty is a punishment for violating the duty.

Note 17. Business Tax Act, Article 51. Such penalty is a punishment for tax evasion.

Note 18. In Taiwan, online auction sites require sellers and buyers to register as an individual rather than a business.

Note 19. A business entity can be interpreted as a private-sector profit-seeking enterprise owned by a government, or jointly owned by a nonprofit-seeking enterprise, institution, organization or association that sells goods or services, and a foreign enterprise, society, institution or organization that has a fixed place of business within Taiwan. (Article 6 of the Business Tax Act)

Note 20. The IRS of the United States applies a list of eight indicators that might prove whether someone's online auctions amount to a business. These indicators include evidence that the taxpayer depends on the income, acts in a businesslike manner, or puts enough time and effort into the activity to suggest a profit motive. (Internal Revenue Service, 2007)

Note 21. Online auction sites will only be required to report customer revenue information if the customer does more than 100 separate transactions in a fiscal year and generates at least $\$ 5,000$ in gross returns. (US Department of the Treasury, 2007)

Note 22. It is the number of positive reviews minus the number of negative reviews a buyer or seller has received.

Note 23. The strategy of evading taxes means that a vendor who a profit-seeking seller does not register as a business.

Note 24. Taiwan's tax authority has offered auditors rewards based on their detection of tax evasion. To increase their financial rewards, tax inspectors have increased the frequency of inspections - this move infuriated the public. Hence, this reward scheme was abolished in 2004. Therefore, when a financial incentive is offered to tax inspectors, $\theta$ can be specified as a function of $F$, and $\theta$ increases as $F$ increases. In this case, an optimal detection cost warrants further research.

Note 25. This model suggests that in the case of non-Internet transactions, $\theta=1$ and $F=0$, the vendor will choose the "not evade" pure strategy and the tax authority will choose a "not inspect" strategy.

Note 26. Website of European Commission Taxation and Customs Union 
(http://ec.europa.eu/taxation_customs/common/links/tax/index_en.htm) is a good portal of learning detailed application of VAT of each Member State.

Note 27. Of course, this form of strategic game deserves to investigate for the future research.

Table 1. Business tax rules for business of different size

\begin{tabular}{|l|l|l|l|l|}
\hline $\begin{array}{l}\text { Monthly sale } \\
\text { revenue of business }\end{array}$ & $\begin{array}{l}\text { Business } \\
\text { registration }\end{array}$ & $\begin{array}{l}\text { Use of } \\
\text { uniform } \\
\text { invoice }\end{array}$ & Tax reporting & $\begin{array}{l}\text { Applicable business } \\
\text { tax rate }\end{array}$ \\
\hline Below NT $\$ 80,000$ & exemption & exemption & exemption & - \\
\hline $\begin{array}{l}\text { NT } \$ 80,000- \\
\$ 200,000\end{array}$ & required & may be exempt & $\begin{array}{l}\text { businesses pay the tax } \\
\text { due assessed by the tax } \\
\text { authority }\end{array}$ & $1 \%$ \\
\cline { 2 - 5 } & granted & $\begin{array}{l}\text { account for and pay the } \\
\text { business tax collected to } \\
\text { the tax administration. }\end{array}$ & $5 \%$ \\
\hline Above NT\$200,000 & required & $\begin{array}{l}\text { required to } \\
\text { issue }\end{array}$ & $\begin{array}{l}\text { account for and pay the } \\
\text { business tax collected to } \\
\text { the tax administration. }\end{array}$ & $5 \%$ \\
\hline
\end{tabular}

Table 2. Scope of seven regions

\begin{tabular}{|l|l|}
\hline Name of the regions & Scope \\
\hline$A_{1}$ & $(\theta \alpha<1-c) \bigcap(\theta \alpha t R>F)$ \\
$A_{2}$ & $(\theta \alpha=1-c) \bigcap(\theta \alpha t R>F)$ \\
$A_{3}$ & $(\theta \alpha>1-c) \bigcap(\theta \alpha t R>F)$ \\
$A_{4}$ & $(\theta \alpha<1-c) \bigcap(\theta \alpha t R=F)$ \\
$A_{5}$ & $(\theta \alpha=1-c) \bigcap(\theta \alpha t R=F)$ \\
$A_{6}$ & $(\theta \alpha>1-c) \bigcap(\theta \alpha t R=F)$ \\
$A_{7}$ & $\theta \alpha t R<F$ \\
\hline
\end{tabular}

Table 3. Existed equilibrium of 7 regions

\begin{tabular}{|l|c|}
\hline Region & Nash equilibrium \\
\hline$A_{1}$ & Equilibrium 1 \\
$A_{2}$ & Equilibrium 1,5 \\
$A_{3}$ & Equilibrium 3 \\
$A_{4}$ & Equilibrium 1,2,4 \\
$A_{5}$ & Equilibrium 1,2,4 \\
$A_{6}$ & Equilibrium 2,4 \\
$A_{7}$ & Equilibrium 2 \\
\hline
\end{tabular}


Table 4. The government's expected payoff in each Nash equilibrium

\begin{tabular}{|l|c|}
\hline Nash equilibrium & Expected payoff in Nash Equilibrium \\
\hline Equilibrium 1 & $\theta \alpha t R-F$ \\
Equilibrium 2 & 0 \\
Equilibrium 3 & $t R-\frac{F}{\theta \alpha}$ \\
Equilibrium 4 & 0 \\
Equilibrium 5 & 0 \\
Equilibrium 6 & $t R-\frac{F}{\theta \alpha}$ \\
\hline
\end{tabular}

Player 1

(Online Retailer)

Player 2 (Government)

\begin{tabular}{|c|c|c|c|}
\hline & & Detect & Not to detect \\
\hline & $\begin{array}{l}\text { Evade (not to } \\
\text { register) }\end{array}$ & $R(1-c-\theta \alpha t), \theta \alpha t R-F$ & $R(1-c), 0$ \\
\hline $\begin{array}{l}\text { Player } 1 \\
\text { (Online Retailer) }\end{array}$ & $\begin{array}{l}\text { Not to evade (to } \\
\text { register) }\end{array}$ & $R(1-c)(1-t), t R-F$ & $R(1-c)(1-t), t R$ \\
\hline
\end{tabular}

Figure 1. Two-player, two-action normal-form game

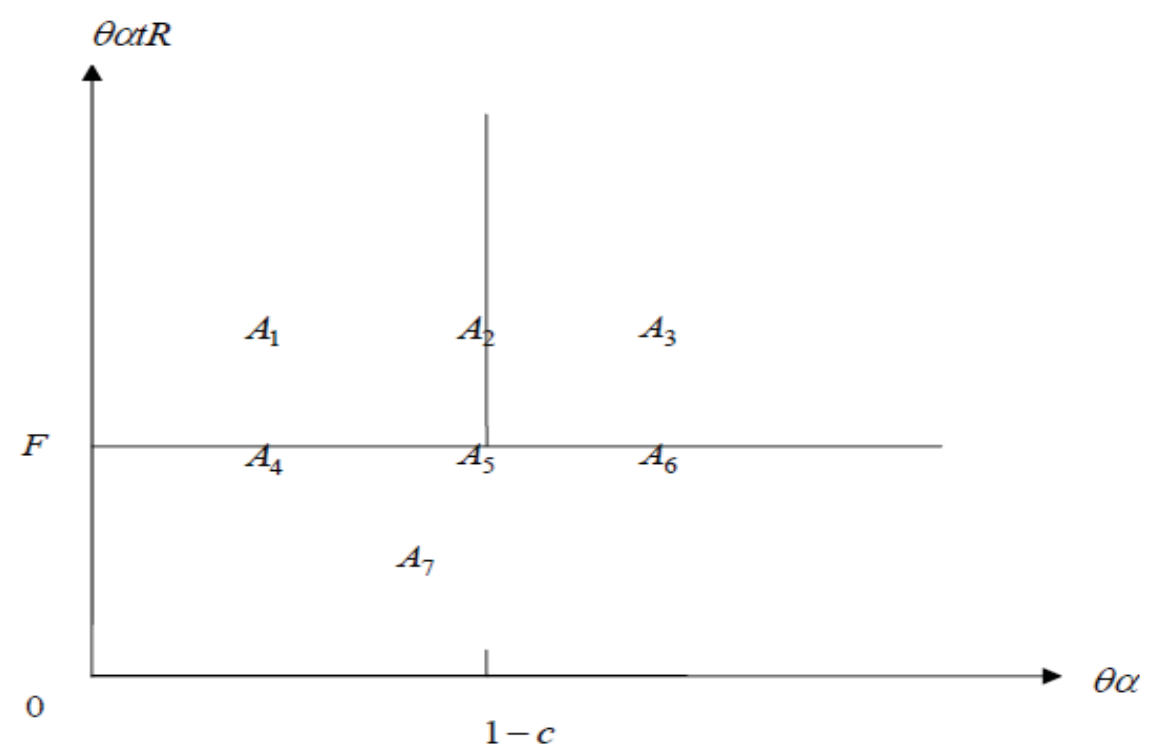

Figure 2. The possible equilibriums when taking $\theta \alpha$ and $\theta \alpha t R$ as two axis 